\section{artelogie}

\section{Artelogie}

Recherche sur les arts, le patrimoine et la littérature de I'Amérique latine

\section{$11 \mid 2017$}

Délocalités, translocalités et activisme dans l'art électronique et biomédiale latino-américain

\title{
Video 3 - Uirapuru (1996/99).
}

Pat Badani interveiws Eduardo Kac (3)

\section{Pat Badani and Eduardo Kac}

\section{(2) OpenEdition \\ Journals}

Electronic version

URL: https://journals.openedition.org/artelogie/1662

DOI: $10.4000 /$ artelogie. 1662

ISSN: 2115-6395

\section{Publisher}

Association ESCAL

Electronic reference

Pat Badani and Eduardo Kac, "Video 3 - Uirapuru (1996/99). ", Artelogie [Online], 11 | 2017, Online since , connection on 21 September 2021. URL: http://journals.openedition.org/artelogie/1662 ; DOI: https:// doi.org/10.4000/artelogie.1662

This text was automatically generated on 21 September 2021.

Association ESCAL 


\section{Video 3 - Uirapuru (1996/99).}

Pat Badani interveiws Eduardo Kac (3)

\section{Pat Badani and Eduardo Kac}

This media file cannot be displayed. Please refer to the online document http:// journals.openedition.org/artelogie/1662 